\title{
DNA barcoding of Fishes, its progress and status in India: A review
}

\author{
Sonakshi Modeel ${ }^{1}$, Bheem Joshi ${ }^{2}$, Tarana Negi ${ }^{3}$, and Ram Negi ${ }^{1}$ \\ ${ }^{1}$ University of Delhi \\ ${ }^{2}$ Zoological Survey of India \\ ${ }^{3}$ Govt. Post Graduate College
}

August 28, 2020

\begin{abstract}
DNA barcoding is based on the assertion that a short standardized genetic sequence is enough for identification of any species. This tool is not only used in species identification but it has remarkable uses in food authentication, discovery of new species and in understanding evolutionary patterns of different populations. Keeping in view the ambiguity in morphological identification methods in fishes and new DNA based methods that has been used widely for species identification; the current review aims to explain all the aspects of DNA barcoding in detail including its current global status, applications and pit faults. Moreover, the article provides special emphasis on Indian Ichthyological studies and status of DNA barcoding in India. The review also explains a brief insight about DNA meta-barcoding, and elucidates the false identification of highly divergent lineages with the example of Ticto Barb (Pethia ticto, Cyprinidae), further suggesting need of appropriate taxonomic works and better computational methods.
\end{abstract}

\section{Hosted file}

DNA barcoding India review (Final Draft).docx available at https://authorea.com/users/354611/ articles/478149-dna-barcoding-of-fishes-its-progress-and-status-in-india-a-review 


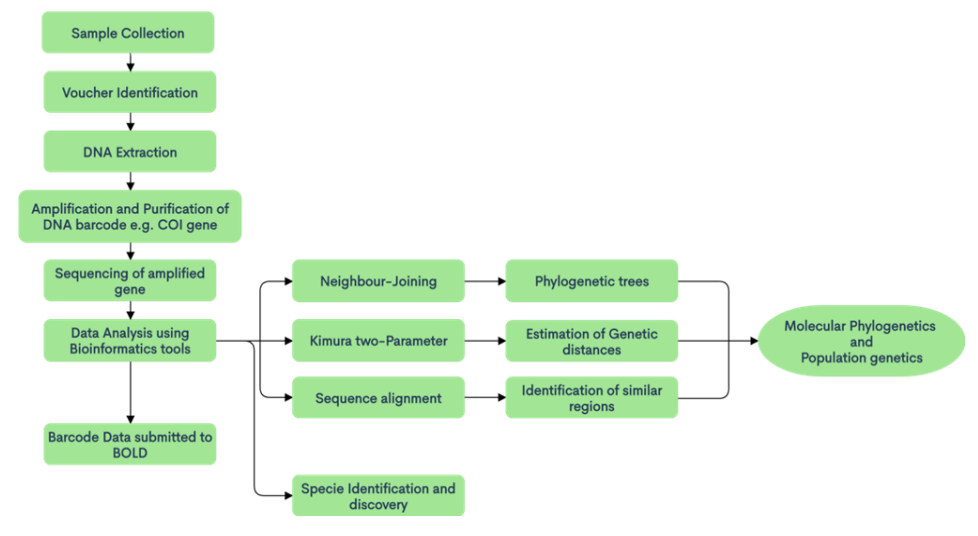

Figure 1: Representation of DNA barcoding methodology and its various bioinformatics analysis techniques for data analysis

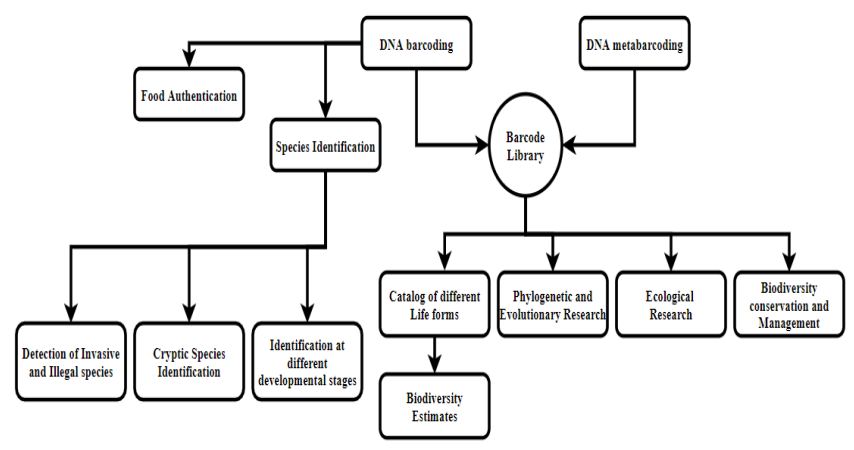

Figure 2: Flow chart representing different applications of DNA barcoding and DNA metabarcoding. 


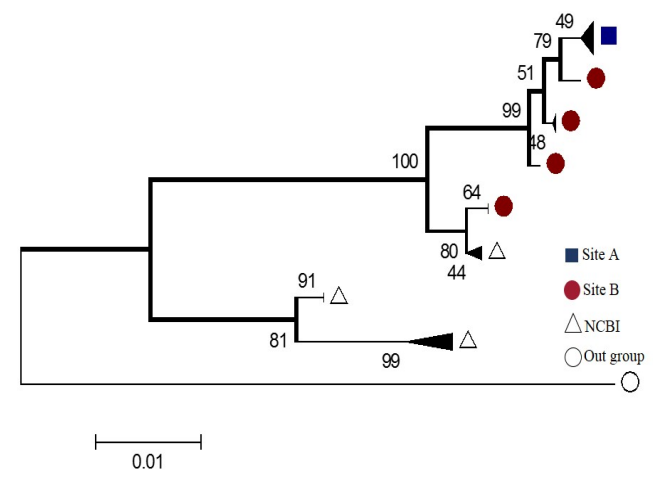

Fig. 3 (a). Pethia ticto sequences two highly divergent clade of $>6 \%$ sequences divergence of the same species.

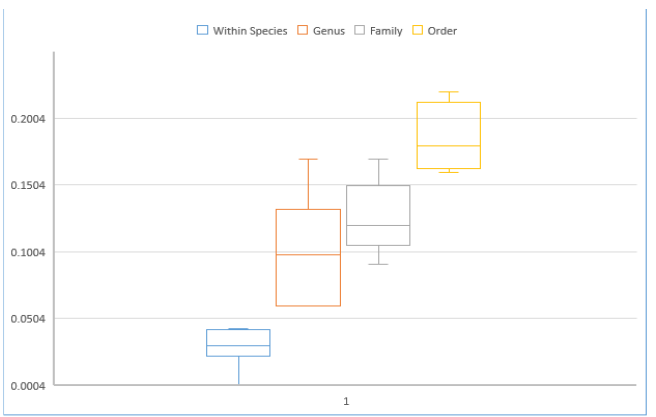

Fig. 3 (b). Sequence divergence ranges between the different operation taxonomic units. 